\title{
Child Participation in Family-School Cooperation
}

Dubravka Maleš $\check{1}^{1}$ Barbara KušEvić ${ }^{* 2}$ AND Ana ŠIranović ${ }^{3}$

$\approx \quad$ This paper discusses the cooperation between families and schools from the perspective of the UN Convention on the Rights of the Child (1989). Given that the principal purpose of the cooperation between families and schools is children's well-being, it is reasonable to expect the child's participation in situations of direct parent-teacher cooperation. The theoretical part of this paper is grounded on contemporary scientific findings in family-school cooperation and the role of the child in the process, while the empirical part seeks to determine whether the requirement for child participation is being fulfilled in family-school cooperation in Croatia. As a theoretical basis for the research, Hart's (1995) 'Ladder of Participation' model has been used; the results can serve as guidelines for improving the existing school practices and introduce changes in school legislation relating to cooperation with parents.

Keywords: Child participation, Family, School, Cooperation

1 Department of Pedagogy, Faculty of Humanities and Social Sciences, Zagreb, Republic of Croatia

$2{ }^{\star}$ Corresponding author. Department of Pedagogy, Faculty of Humanities and Social Sciences, Zagreb, Republic of Croatia; bkusevic@ffzg.hr

3 Department of Pedagogy, Faculty of Humanities and Social Sciences, Zagreb, Republic of Croatia 


\section{Udeležba otroka pri sodelovanju šole in družine}

Dubravka Maleš, Barbara KušEvić* IN ANa ŠIranović

\& V prispevku razpravljamo o sodelovanju med družino in šolo z vidika Konvencije ZN o otrokovih pravicah (1989). Glede na to, da je glavni namen tega sodelovanja otrokovo dobro počutje/blaginja, se pri neposrednem sodelovanju staršev in učiteljev upravičeno pričakuje udeležba otroka. V teoretičnem delu razpravljamo o trenutnih znanstvenih ugotovitvah o sodelovanju med šolo in družino ter o vlogi otroka v tem procesu; v empiričnem delu ugotavljamo, ali je zahteva po vključitvi otroka pri sodelovanju družine in šole na Hrvaškem izpolnjena. Kot temeljno teoretično izhodišče za raziskavo je bila uporabljena Hartova (1995) "lestvica udeleženosti«; izsledki lahko služijo kot smernice za izboljšanje trenutne šolske prakse in kot predlogi sprememb v šolski zakonodaji na področju sodelovanja s starši.

Ključne besede: udeležba otrok, družina, šola, sodelovanje 


\section{Introduction}

The UN Convention on the Rights of the Child (1989) has created a Copernican revolution in the perception of the child. This international document acknowledges that the child is a subject with rights; consequently, for the first time in history, the child is seen as holder of rights, and not merely an object of adult protection.

This new image of the child has affected not only children, but also those who care for them and educate them, and are responsible to ensure that they enjoy their rights. Parenting has thus ceased to be a matter of privacy, and entered into the public domain. Because the rights of the child are guaranteed by national laws, any violation of those rights by a parent or any other adult requires national authorities' legal protection of the child's integrity. However, the extent to which children enjoy their rights also depends upon adults' attitudes towards them. Adults are thus required to alter their attitudes in a way that they respect children's rights and recognise each child's individuality. Sadly, adults are often the ones who hinder children from exercising their rights, since they still frequently hold the traditional image of the child as someone in need of protection, and not as subject with rights and agency. The child is, therefore, often seen merely as a future adult and childhood a transitional period, namely a preparation for the adulthood (Verhellen, 2001). Nevertheless, from the viewpoint of seeing the child as subject with rights, every child is regarded an individual, and childhood is a period in which children live their rights, rather than waiting for their time to come.

\section{Participation rights - a reflection of the new perception of the child's nature}

Based on the concept of the child as subject with rights, the Convention on the Rights of the Child has brought forth a set of rights demanding that the child's voice be heard and taken into consideration. These are known as participation rights, and they guarantee children's active involvement in society. It is precisely these rights that have made a substantial shift in the acceptance of the child as an active member of his/her community. Participation rights reflect a belief in the child's abilities to be actively involved in his or her growth and the development of the environment in which he or she lives and learns.

Participation is expressed in two ways in the Convention: as one of the four guiding principles of the Convention (together with those of non-discrimination, the right to life, survival and development and adherence to the best interests of the child), and as the core of a set of rights that guarantees children 
participation in their social context. The right to participate is explicitly stated in several articles of the Convention, while in others it is implicit (Flekkøy \& Kaufman, 1997). Article 12 states that the child who is capable of forming his or her own views has the right to express those views freely in all matters affecting the child and that the views of the child are given due weight in accordance with his or her age and maturity (Convention on the Rights of the Child, 1989). In addition to Article 12, participation is explicitly stated in Article 13 (the right to freedom of expression and freedom to seek, receive and impart information and ideas of all kinds, regardless of limits, either orally, in writing or in print, in the form of art, or through any other media of the child's choice), Article 14 (the right of the child to freedom of thought, conscience and religion), Article 15 (the rights of the child to freedom of association and peaceful assembly), Article 31 (the right to participate freely in cultural life and the arts), and Article 40 (the right to participate in legal proceedings against the child).

In other parts of the Convention, participation is also rather implied than overtly stated. The preamble of the Convention states that the child should be fully prepared to live an individual life in society (Convention on the Rights of the Child, 1989). Having that in mind, it is unfair to expect a young person coming of age to know how to participate in the grown-up world if he/she has not actively participated prior to adulthood and thus practiced a variety of participatory mechanisms (Flekkøy \& Kaufman, 1997). In that respect, Article 5 of the convention states that the child's parents and other educators have to provide appropriate direction and guidance for their children. Adult guidance does not imply making decisions for children or taking control over their lives. Rather, it supposes that the adults gradually involve children in decision making about all issues that affect them. Growing-up is thus seen as a process of gradual empowerment and a period of learning how to take responsibility for one's own actions, which is not possible if the child's participation rights are not respected.

In addition to legal obligations of child participation set forth by the Convention on the Rights of the Child, research has also shown that participation has its developmental and educational value. Active involvement supports a sense of group membership, collective ownership and shared responsibility (Hart, 1992; Lansdown, 2001). It facilitates the development of collaborative decision making and problem solving (Smith, 2007), as well as the development of skills for taking control over one's own life (Carr, Lee, \& Jones, 2005, in Smith, 2007) and for changing the adverse conditions of life (Razzini \& Thaplyial, 2005, in Smith, 2007; Lansdown, 2001). A sense of control over oneself and one's actions supports the process of assuming responsibility for one's behaviour, as illustrated by Wood, Larson and Brown's research (2009). 
Their research showed that young people who participated in various youth programs 'reported becoming more responsible through their participation' because of their 'adherence to their commitments and their consideration of the consequences of their actions on others' (2009, p. 295).

Student councils and class and school projects are often considered to be key mechanisms for practicing participation in schools. However, our belief is that genuine student participation implies that school life is holistically permeated with participatory principles. Student participation and collaborative conduct must be reflected in everyday school life, patterns of communication and parent-teacher-student relations. Therefore, the next chapter discusses the necessity of involving students in processes of family-school cooperation.

\section{Child participation in family-school cooperation}

Schooling is one of a child's most essential activities. It affects the child's entire cognitive, social and emotional development. Given that the child spends most of his or her time with his or her family or in school, not only is it crucial how the two institutions perceive participation rights, but also to what extent they are coordinated in the promotion of child participation. Since both family and school constitute significant sources of influence on the psycho-educational development of children, the best results are achieved when these two institutions work together (Comer \& Hayness, 1991). Family-school cooperation ${ }^{4}$ is one such mutual area of activity in which participation rights can be both respected and denied, depending on the context and quality of cooperation.

Family-school cooperation is defined in this paper as the process of reciprocal information-sharing, counselling, learning, arranging and spending time together, with the aim of sharing responsibility for the child's development in family and school (Maleš, 1996). Therefore, the principal objective of family-school cooperation is the child's well-being. The importance of parent involvement in the child's school life has been repeatedly confirmed. For instance, it has been shown that the chief prediction of the child's school success or failure is not the family's socio-economic status, nor its culture or structure, but parent involvement in the child's learning and development (Clark, 1983; Dornbush et al., 1987, all in Amatea, 2008). This is crucial to any educational institution when evaluating their approach to families. If teachers acknowledge that parents are competent, because they know their children best and strongly

4 The authors primarily focus on family-school cooperation, while the empirical part further elaborates the cooperation between family and other educational institutions, such as kindergartens, children's homes and other. 
influence their school progress, then one can expect that they will find ways to reach out to parents, hear them out, detect their strong points and use all the knowledge parents have to improve the child's developmental outcomes.

If the principle objective of family-school cooperation is indeed the child's well-being, then it is reasonable to expect that the child be given an active role in situations of direct family-school cooperation, in the light of Article 12 of the Convention, which emphasises the right of the child to express his or her own views freely in all matters affecting him or her. Paradoxically, researchers and practitioners seem to be more interested in teachers' and parents' roles in the process, while the child is usually treated as a passive object of adult care. For instance, Olsen and Fuller (2008) discuss child participation in parent-teacher conferences only incidentally, as an option decided upon by teachers and parents and never by children, and dependent upon the child's age and the purpose of the child's participation. Epstein (2001) indicates the following roles of the child in family-school cooperation: courier, communicator, commentator, observer and targets of attention in both settings, also fairly detached from the perception of the child as an agent and subject equal to adults in the process of decision making.

Such practices are in conflict with the concept of participation rights, which imply the child's active involvement in all activities of family-school cooperation, such as the possibility to express his or her views freely, propose solutions to problems, or even organise a family-school meeting by him/herself. It is the child's fundamental right that protects not only the child's best interests, but also supports enhanced decision-making, since children possess unique knowledge (Lansdown, 2001) of themselves, of which adults may not be aware. These arguments are respected in Hart's 'Ladder of Participation' model (1992), which incorporates eight levels of participation of children in projects. The authors of the paper used Hart's model as a theoretical framework for their research. The model is presented in the following chapter.

\section{Theoretical framework of the research - Hart's 'Ladder of Participation' model}

Hart's (1992) 'Ladder of Participation' of children in projects is a model of children's involvement in collaborative activities with adults. The first three levels of the ladder (manipulation, decoration, tokenism) are, in fact, examples of pretend participation, i.e. non-participation, which is characterised by adults' use of children for the fulfilment of their own goals. The purpose of the pretend participatory levels is to point to situations where it may seem that children participate, when, in fact, they are excluded (Shier, 2001). The next five levels 
(assigned but informed; consulted and informed; adult initiated, shared decisions with children; child initiated and directed; child initiated, shared decisions with adults) represent situations of genuine and gradually empowering child participation. Table 1 presents Hart's 'Ladder of participation' model.

Table 1. Levels of Hart's 'Ladder of Participation' model (in Hart, 1992).

\begin{tabular}{ll}
\hline Level name & Description of the form of participation \\
\hline Manipulation & $\begin{array}{l}\text { Adults use children's ideas, but do not give any feedback on how they } \\
\text { were used. Children have no real understanding of their roles. }\end{array}$ \\
\hline Decoration & $\begin{array}{l}\text { Children participate, but the purpose of their participation is known } \\
\text { solely to adults. Children are used to fulfil adults' goals. }\end{array}$ \\
\hline Tokenism & $\begin{array}{l}\text { Children are asked for their opinions, but have little or no choice about } \\
\text { the way they will express them or the scope of the ideas they can } \\
\text { express. }\end{array}$ \\
\hline Assigned but informed & $\begin{array}{l}\text { Children are familiar with who made the decision about their participa- } \\
\text { tion in the project; they understand the aim of the project and the } \\
\text { purpose of their participation. They volunteer to participate. }\end{array}$ \\
\hline Consulted and informed & $\begin{array}{l}\text { The project is designed and managed by adults who consult children. } \\
\text { Children understand the process and their opinions are taken into } \\
\text { consideration. }\end{array}$ \\
\hline $\begin{array}{l}\text { Adult-initiated, shared } \\
\text { decisions with children }\end{array}$ & \begin{tabular}{l} 
Children participate in decision-making together with adults. \\
\hline $\begin{array}{l}\text { Child-initiated and } \\
\text { directed }\end{array}$
\end{tabular} \\
\hline $\begin{array}{l}\text { Child-initiated, shared } \\
\text { decisions with adults }\end{array}$ & $\begin{array}{l}\text { Children plan the project and decide how it is to be carried out. Adults } \\
\text { involve adults as support. }\end{array}$ \\
\hline
\end{tabular}

The model has been repeatedly adapted and variously interpreted. For instance, Shier (2001) devised a five-level model of child participation. At each level, he argues, 'individuals and organizations may have differing degrees of commitment to the process of empowerment' clarified 'by identifying three stages of commitment at each level: openings, opportunities and obligations' (Shier, 2001, p. 110). Jensen, in contrast, suggested that the rungs of the ladder are described as 'different forms rather than different levels of participation' (Jensen, 2000, in Hart, 2008, p. 23), while Treseder (1997, in Hart, 2008) developed a circular model, and Mannion (2003, in Hart, 2008) devised something similar to a fountain of participation.

Reddy and Ratna (2002) developed an intriguing adaptation of Hart's model which reflects upon different roles that adults play in relation to child participation. They suggested two additional levels of non-participation to be placed below Hart's pretend participatory levels - active resistance of child participation, and hindrance to child participation, by which adults intentionally or unintentionally undermine children's abilities or make them feel incompetent. 
We used Hart's 'Ladder of Participation' model as the theoretical framework for our research. As far as we are aware, the model has not yet been used for examining the scope of child participation in family-school cooperation. The methodology of the research on the existing practices of child participation in parent-pedagogue ${ }^{5}$ cooperation in schools in Croatia is presented in the next chapter.

\section{Method}

The main research question was to determine the most frequent levels of child participation in situations of direct parent-pedagogue cooperation in various educational institutions. Eight levels of Hart's 'Ladder' were used as a framework for investigating the practices of child participation in the processes of tackling various educational issues, which usually takes place during parentpedagogue consultation. In that sense, the consultation process was imagined as a collaborative activity between adult and child, and Hart's model adapted accordingly, as presented in Table 2.

Table 2. Adaptation of Hart's 'Ladder of Participation' model to parentpedagogue cooperation.

\begin{tabular}{ll}
\hline Level name & Description of the form of participation \\
\hline Manipulation & $\begin{array}{l}\text { Parent and pedagogue are familiar with the child's views, which they } \\
\text { may use without the child's awareness. Adults make all the decisions } \\
\text { by themselves. }\end{array}$ \\
\hline Decoration & $\begin{array}{l}\text { The child has to attend parent-pedagogue consultation, even if he/she } \\
\text { does not understand the reasons for his/her participation. Adults make } \\
\text { all the decisions by themselves. }\end{array}$ \\
\hline Tokenism & $\begin{array}{l}\text { The child is given an opportunity to state the facts of an event, without } \\
\text { his/her own interpretation of the event. }\end{array}$ \\
\hline Assigned but informed & $\begin{array}{l}\text { The child is familiar with the reasons of parent-pedagogue consulta- } \\
\text { tion and aware of his/her role. The child can freely decide to partici- } \\
\text { pate, or not to participate. }\end{array}$ \\
\hline Consulted and informed & $\begin{array}{l}\text { The child volunteers to attend parent-pedagogue consultation. He/she } \\
\text { freely expresses opinions, which adults take seriously and inform the } \\
\text { child about the outcomes of the meeting. }\end{array}$ \\
\hline $\begin{array}{l}\text { Adult-initiated, shared } \\
\text { decisions with children }\end{array}$ & $\begin{array}{l}\text { The child is actively involved in parent-pedagogue consultation, sug- } \\
\text { gests possible solutions to problems, and decides upon the best one } \\
\text { together with adults. }\end{array}$ \\
\hline $\begin{array}{l}\text { Child-initiated and } \\
\text { directed }\end{array}$ & $\begin{array}{l}\text { The child suggests possible ways to solve problems, while parent and } \\
\text { pedagogue try to help the child find the best solution. The child makes } \\
\text { the final decision by him/herself. }\end{array}$ \\
\hline $\begin{array}{l}\text { Child-initiated, shared } \\
\text { decisions with adults }\end{array}$ & $\begin{array}{l}\text { The child initiates parent-pedagogue consultation with the aim of } \\
\text { jointly deciding on the best solution to a problem. }\end{array}$ \\
\hline
\end{tabular}

5 In the Croatian educational system a pedagogue is an educator who, among many other duties (from administrative to managerial) does student and parent counseling for the purpose of preventing or dealing with various educational and other problems. 
The instrument was designed by the authors of the paper on the basis of Hart's 'Ladder of Participation' model (Table 2). It consists of three sections: 1. general data (type of educational institution, location of employment institution and age of respondent);

2. frequency of involving children in consultation with parents;

3. eight graded levels of child participation in parent-pedagogue consultation.

Reliability analysis of the questionnaire produced Cronbach's alpha coefficient of 0.79 .

A total of 217 pedagogues who work in various educational institutions in the Republic of Croatia participated in the research. Almost two thirds of the respondents work in elementary schools (64.5 per cent), while substantially smaller number of respondents works in secondary schools (14.7 per cent), kindergartens (11.1 per cent) or some other educational institution (9.7 per cent).

With regard to location of employment institution, the majority of respondents works in urban areas (77.3 per cent), while the rest of the respondents work in smaller rural areas (16.1 per cent) or municipalities (11.5 per cent).

With regard to age of the respondent, our average respondent was between 41 and 50 years old. This particular age span covers more than a third of all respondents, while the smallest number covers those aged 6o+. The distribution by age is presented in Table 3 .

Table 3. Age of respondents.

\begin{tabular}{lcc}
\hline Age groups & $\mathbf{f}$ & $\%$ \\
\hline under 30 years & 45 & 20.7 \\
\hline 31-40 years & 36 & 16.6 \\
\hline $41-50$ years & 78 & 35.9 \\
\hline $51-60$ years & 52 & 24.0 \\
\hline 61 years + & 6 & 2.8 \\
\hline Total & 217 & 100.0 \\
\hline
\end{tabular}

\section{Findings and discussion}

We aimed to investigate several things. Firstly, we wanted to determine general practices of involving children in individual consultations with their parents, frequency of child involvement, and the reasons for their involvement. By doing so, we wanted to see how pedagogues perceive the role of the child in situations of the child's direct concern, which parent-pedagogue consultation 
certainly is. The results (Table 4) suggest that the majority (75.6 per cent) involves children often or always. Almost two thirds of the respondents believe child participation is the best way to come to solutions to problems, while a tenth of the respondents who always involve children believe that participating in parent-pedagogue consultation is the child's right. A smaller but nonetheless significant number (one fifth) of respondents involve children rarely, while 3.7 per cent of respondents never involve children.

Table 4. Frequency of involving children in individual consultation with parents.

\begin{tabular}{lcc}
\hline Description of frequency & $\mathrm{f}$ & $\%$ \\
\hline Never, it is a matter between us adults & 8 & 3.7 \\
\hline Rarely, when it is necessary in order to solve problems & 45 & 20.7 \\
\hline $\begin{array}{l}\text { Often, because I believe it is the best way to come to a solution to } \\
\text { a problem }\end{array}$ & 138 & 63.6 \\
\hline $\begin{array}{l}\text { Always, the child has the right to know what is discussed with } \\
\text { regards to him/her }\end{array}$ & 26 & 12.0 \\
\hline Total & $\mathbf{2 1 7}$ & 100.0 \\
\hline
\end{tabular}

The respondents who involve children never or rarely (24.4 per cent) stated different reasons for such practices. The respondents had the possibility to choose more than one answer. The most frequent reasons were: it is easier to talk to a parent when the child is not present (40.4 per cent), to avoid parentchild confrontations ( 34.6 per cent), to protect the child from embarrassment (23.1 per cent).

Although the greatest number of respondents who do not include children do so for the reason of protecting the child (from embarrassment or confrontation with a parent), which is indeed in legitimate some cases, excluding children from the processes which affect them directly goes against the Convention's basic principles and the concept of participation rights. It is even more problematic when children are excluded from facilitating the consultation process, which is in fact the most frequent reason. Since the purpose of the cooperation between family and educational institution is the child's well-being, it is precisely the child's well-being (and not making the work of school services easier) that should be the prime reason for all cooperative activities. Even if it is indeed easier to consult with parents without the child's presence, such consultation is deprived of the child's specific views and suggestions for solutions, as well as opportunities to stand up for him/herself and make decisions, all of which are skills that the child will surely need in the future.

After examining the way pedagogues perceive the role of the child in situations of the child's direct concern, the respondents were presented with 
eight graded statements representing different levels of child participation in parent-pedagogue consultation (Table 2). Frequency of the occurrence of participatory practices was determined on a scale from 1 to 5,1 denoting never, 2 rarely, 3 sometimes, 4 often and 5 always. The results were first analysed separately for every level of the model, and then in correlation with type of educational institution, location of employment institution and age variables. To determine to what degree the practices of child involvement in parentpedagogue consultation are actually present, as well as for the reason of greater clarity of the findings, we summarised the results of frequency denominators never + rarely and often + always for each level of the model.

Figure 1 presents the percentage of the respondents who answered that they involved children often and always on different levels of the model.

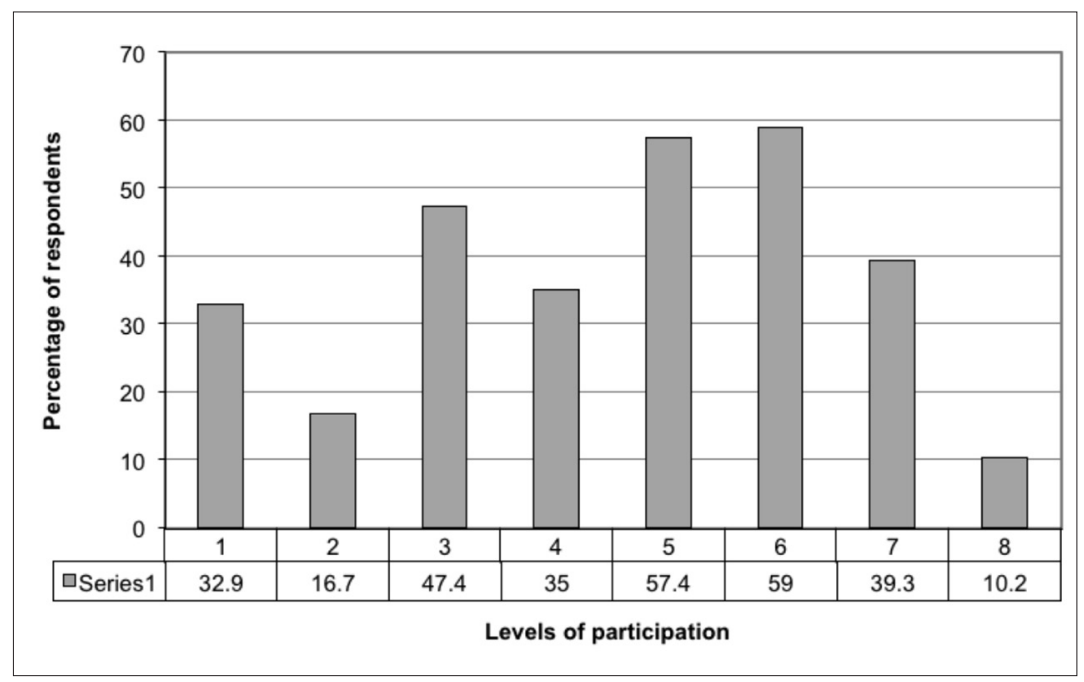

Figure 1. Children involved often/always in individual parent-pedagogue consultation.

Given that the first three levels represent pretend child participation, while the next five represent genuine participation, a regular distribution of results on the levels of genuine participation ( 4 to 8 ) is discernible from Figure 1. The greatest number of respondents (59 per cent) stated that they involved children on the sixth level, adult initiated, shared decisions with children, which implies the child's active involvement in parent-pedagogue consultation, his/her active contribution to problem-solving and joint child-adult decision-making. A fairly large number of respondents stated that they involved children often 
or always on the fifth level, consulted and informed, which implies the child's participation by his/her free will, as well as opinion-stating taken into serious consideration. Generally, the findings suggest that fairly positive practices of child participation in family-school cooperation exist in Croatian schools.

However, only 10.2 per cent of respondents stated that they involved children on the last level of the 'Ladder'. Nevertheless, such results are not disconcerting since, according to Hart (2008), participation on the highest levels of the 'Ladder' is not obligatory. Rather, it is vital that children are given opportunities to ultimately reach those levels. However, it is worth noting that we expected such small percentage of responses concerning child participation on the highest level of the 'Ladder' because such participation implies a wholly novel perception of the child and adult-child relationship. By encouraging such child participation, the adult has to gradually renounce his/her absolute power and authority over the child.

In contrast, the responses that suggest that children are often or always involved on the levels of pretend participation (Levels 1, 2 and 3) are somewhat disturbing. Figure 1 shows that, except for on the decorative level, pretend child participation is practiced often or always by almost a third of all respondents. However, the lack of decorative participatory practices can be explained by the fact that that level was, in our instrument, defined in a negative manner. That is to say, on the decorative level, the child is required to attend parentpedagogue consultation, even if he/she does not understand the reasons for his/her participation, while adults make all the decisions by themselves. Such a depiction could have prompted the respondents to give what they considered desirable or appropriate responses, by which they denied the existence of decorative practices in their work with parents and children. Furthermore, the decorative level is the only level described in an explicitly negative manner.

Additionally, almost half of the respondents stated that they involved children on the third level of pretend participation (tokenism), which we find alarming. Such findings suggest that every other Croatian pedagogue insists that the child does not give his/her version of an event or a problem, but that he/she states mere facts. Moreover, such practices suggest that the majority of respondents still do not recognise the importance of the child's unique knowledge of him/herself nor the child's possible contributions to joint problem-solving.

In order to obtain a more complete outlook on the practices of child participation in parent-pedagogue consultation, it is crucial to examine the percentage of respondents who rarely or never involve children on different levels of the model (Figure 2). 


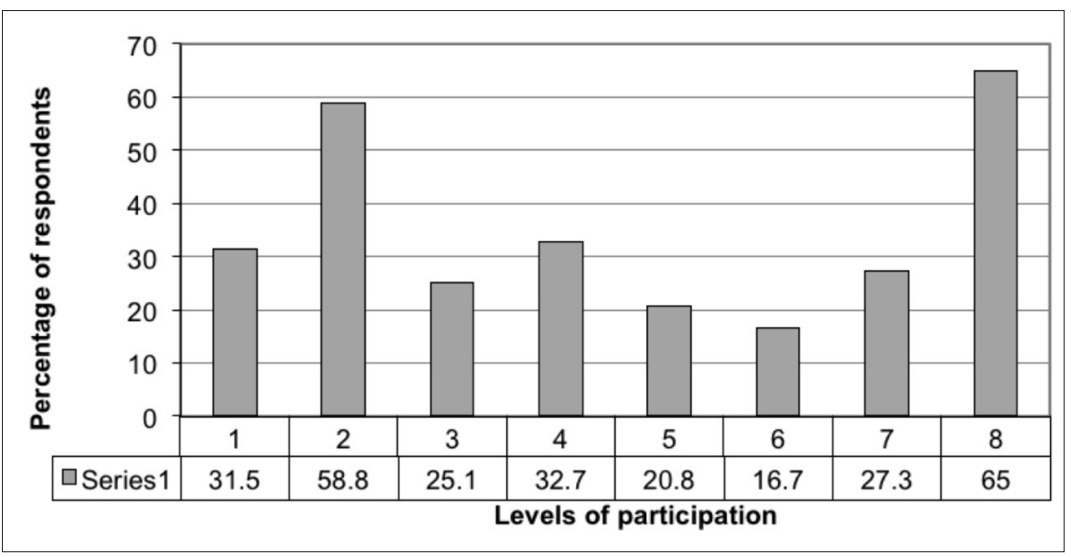

Figure 2. Children involved rarely/never in individual parent-pedagogue consultation.

The findings are compatible with the results for often/always frequency denominators. They also confirm that child participation is less frequent on Levels 6, 7 and 8 of the model, as well as on Level 2 (pretend participation), probably for the reasons suggested above.

In general, the overall findings imply that there is not one dominant level of participation practiced in parent-school cooperation in Croatian schools, but that the most frequently practiced levels are those positioned centrally in the model. Concerning the levels of genuine child participation, the lower levels of the ladder are most frequently practiced; in relation to pretend participation, manipulation and tokenism are most common in Croatian educational institutions.

We also wanted to determine whether there existed any differences in child participation with regard to type of educational institution and location of employment institution, as well as age of respondents. For that purpose, we used a regression analysis. The independent variables consisted of the type of educational institution and the location of employment institution, while the criterion variables consisted of each of the eight levels of the model of participation.

The examination shows that the independent variable of location of employment institution is statistically significant only in relation to decoration, but not in relation to other levels of the model of participation. Furthermore, the age of respondents proves not to be statistically significant in relation to different levels of participation. This suggests that there is no statistically relevant difference between the frequency of different participatory practices in 
relation to the location of employment institution, nor the age of respondents. The lack of correlation between age of respondents and the practices of child involvement in parent-pedagogue consultation is somewhat surprising, since it is reasonable to expect that younger pedagogues have different concepts of the child's role in the processes of cooperation with parents than older pedagogues, due to differences in their education and the powerful influence the Convention has had in the previous twenty years. Therefore, we suggest that future research focuses on the nature of the connection between age of respondents and location of employment institution and the possibilities of child participation in parent-pedagogue cooperation.

The type of educational institution was shown to be in correlation with all three levels of pretend participation (beta coefficient 0.191 for manipulation, 0.183 for decoration, 0.324 for tokenism), as well as with the five levels of genuine participation (beta coefficient 0.284 for assigned but informed, 0.310 for consulted and informed, 0.261 for adult initiated, shared decisions with children, 0.311 for child initiated and directed and 0.313 for child initiated, shared decisions with adults). These findings confirm that the institutional framework is indeed a factor in the nature of child participation. Moreover, it is reasonable to expect that the conception of the child's capabilities to participate differs given different types of institution (early childhood education institution in comparison to secondary school) since the concept of the child is significantly determined by the child's developmental characteristics. Nevertheless, even pre-school children are in fact competent to express their views. Therefore, the respect of their participation rights is equally valuable as of those attending elementary and secondary schools. Since the way the instrument was constructed does not allow unambiguous determination of the nature of the relationships between the variables in question (therefore, the interpretation is based solely upon logical assumptions), the findings can serve as an initial indicator of the diverse roles the child can play in the processes of parent-pedagogue cooperation. The nature of these relationships should be investigated more thoroughly in the future.

\section{Conclusion}

The research sheds some light on the practices of involving children in the processes of direct parent-pedagogue cooperation. An adaptation of Hart's 'Ladder of Participation' served as guidance for examining these practices. The findings suggest the existence of different forms of child participation in parentpedagogue consultation: from a complete lack of participation, through pretend 
participation, to genuine participation characterised by the child's agency in decision-making. Such findings point to a gradual shift in the perception of the nature of adult-child relationship. It should be emphasised that the real complexities of parent-pedagogue cooperation and the role of the child in the process had to be reduced in order to fit the eight levels of Hart's 'Ladder'. Therefore, the approach described in the paper does not serve as a framework for evaluating respondents' educational work, just as Hart's participatory model is not an evaluative tool. Quite the opposite: these kinds of analyses should encourage critical examination of the child's role in educational institutions, and of the extent to which children's participation rights are respected. If this is taken into consideration, the findings can serve as a motivation for improving the existing school practices and introducing changes in school legislation in relation to the cooperation with parents, as well as for raising awareness about the importance of respecting the rights of the child in education.

\section{References}

Amatea, E. S. (2008). Building culturally responsive family-school relationships. Upper Saddle River, New Jersey: Pearson.

Comer, J. P., \& Hayness, N. M. (1991). Parent Involvement in Schools: An Ecological Approach. The Elementary School Journal, 91(3), 271-277.

Epstein, J. L. (2001). School, Family and Community Partnership. Colorado: Westview Press. Flekkøy, M. G., \& Kaufman, N. H. (1997). The Participation Rights of the Child. London: Jessica Kingsley Publishers Ltd.

Hart, R. A. (1992). Children's Participation: from Tokenism to Citizenship. Florence: UNICEF International Child Development Centre.

Hart, R. (2008). Stepping Back from ‘The Ladder': Reflections on a Model of Participatory Work with Children. In Reid, A. (Ed.), Participation and Learning. Perspectives on Education and the Environment, Health and Sustainability (pp. 19-31). Dordrecht: Springer.

Lansdown, G. (2001). Promoting Children's Participation in Democratic Decision-Making. Florence: United Nations Children's Fund.

Maleš, D. (1996). Od nijeme potpore do partnerstva između obitelji i škole. Društvena istraživanja, $1(21), 75-88$.

Olsen, G., \& Fuller, M. L. (2008). Home-School Relations. Working Successfully with Parents and Families. Boston: Pearson.

Reddy, N., \& Ratna, K. (2002). A Journey in Children's Participation. Vimanapura, Bangalore: The Concerned for Working Children.

Shier, H. (2001). Pathways to Participation: Openings, Opportunities and Obligations. Children \& Society, 15(2), 107-117. 
Smith, A. B. (2007). Children and Young People's Participation Rights in Education. International Journal of Children's Rights, 15(1), 147-164.

United Nations Convention on the Rights of the Child. Retrieved June 152010 from http://www2. ohchr.org/english/law/pdf/crc.pdf

Verhellen, E. (2001). Facilitating Children's Rights in Education: Expectations and demands on teachers and parents. In Hart, S. et al. (Eds.), Children's Rights in Education (pp. 223-231). London: Jessica Kingsley Publishers.

Wood, D., Larson, R. W., \& Brown, J. R. (2009). How Adolescents Come to See Themselves as More Responsible Through Participation in Youth Programs. Child Development, 8o(1), 295-309.

\section{Biographical note}

Dubravka Maleš, Ph.D. is Full Professor at the Department of Pedagogy at the Faculty of Humanities and Social Sciences, University of Zagreb. The family as a factor in childhood education, the issues of co-operation between family and educational institutions and the human and child's rights are in the focus of her scientific interest. She is the chief editor of journal Zrno (Seed), a journal for the family, nursery school and primary school and author or co-author of ten books, more than fifty scientific and professional papers in the field of family pedagogy, early childhood development and education for human and child's rights.

BARBARA KušEvić, $\mathrm{PhD}$, works as a research and teaching assistant on the project New paradigms of early childhood education at the Department of Pedagogy at the Faculty of Humanities and Social Sciences, University of Zagreb. The special area of her interest is family studies. In that area in 2013 she defended her doctoral thesis, dealing with child-rearing implications of delayed parenting. She published three book chapters and a dozen of scientific and professional papers in Croatia and abroad.

ANA ŠIrANOvić, works as a research and teaching assistant on the project New paradigms of early childhood education at the Department of Pedagogy at the Faculty of Humanities and Social Sciences, University of Zagreb. The special area of her interest are human and children's rights. She published several scientific and professional papers in Croatia and abroad. Currently she is writing her doctoral thesis in the field of children's rights. 